\title{
RESPON PERTUMBUHAN, KONSUMSI PAKAN DAN UMUR DEWASA KELAMIN HASIL PERKAWINAN SILANG PUYUH HYBRID DENGAN COTURNIX COTURNIX JAPONICA
}

\section{Response The Growing Consumption Woof and Adult Of Genders Age Which is Resulted by Crosswise Mating Of Hybrid Quail With Coturnix coturnix japonica}

\author{
Yuyun Fahrina ${ }^{1}$, M. Aman Yaman $^{1 *}$, Herawati Latif ${ }^{1}$ \\ Program Studi Peternakan, Fakultas Pertanian, Universitas Syiah Kuala
}

\begin{abstract}
Abstrak. Puyuh (Coturnix coturnix japonica) merupakan jenis unggas yang paling populer selain ayam dan itik di Indonesia yang diminati peternak unggas. Namun kendala utama dalam perkembangan puyuh yaitu kurang tersedianya bibit puyuh hasil persilangan dengan struktur breeding yang jelas sehingga dikhawatirkan terjadinya inbreeding. Sehingga perlu dilakukan penelitian persilangan (Cross breeding) puyuh Hybrid dengan Coturnix coturnix japonica terhadap pertumbuhan turunannya. Tujuan dari penelitian ini yaitu untuk mengetahui pengaruh persilangan puyuh Hybrid terhadap pertumbuhan, konsumsi pakan, pertambahan bobot badan dan umur dewasa kelamin turunannya. Hasil penelitian menunjukkan bahwa persilangan puyuh Hybrid dengan Coturnix coturnix japonica tidak berpengaruh nyata $(\mathrm{P}>0,05)$ terhadap konsumsi pakan, pertambahan bobot badan, konversi pakan dan umur bertelur pertama turunannya. Namun dari hasil persilangan jantan Coturnix coturnix japonica dengan betina Hybrid memperlihatkan bahwa angka konversi pakan cenderung lebih efisien dan umur bertelur pertama lebih cepat.
\end{abstract}

Kata Kunci : Puyuh, Persilangan, Inbreeding, Crossbreeding, Konsumsi pakan, Konversi Pakan

\begin{abstract}
Quail (Coturnix coturnix japonica) is the most popular type of poultry besides chickens and ducks in Indonesia that are favored by poultry farmers. But the main obstacle in the development of quail is the lack of availability of quail seeds from crosses with a clear breeding structure that is feared to occur inbreeding. So it is necessary to do a hybrid quail cross breeding study with Coturnix coturnix japonica on its derivative growth. The purpose of this study is to determine the effect of Hybrid quail crosses on growth, feed consumption, body weight gain and adult age of hereditary sex. The results showed that Hybrid quail crossing with Coturnix coturnix japonica had no significant effect $(\mathrm{P}>0.05)$ on feed consumption, body weight gain, feed conversion and age of first laying eggs. However, the results of Coturnix coturnix japonica male Hybrids with Hybrid females show that feed conversion rates tend to be more efficient and the age of first laying is faster.
\end{abstract}

Keywords: Quail, Crossing, Inbreeding, Crossbreeding, Feed consumption, Feed conversion

\section{PENDAHULUAN}


Puyuh (Coturnix coturnix japonica) merupakan jenis unggas yang paling populer selain ayam dan itik di Indonesia yang diminati peternak unggas. Namun kendala utama dalam perkembangan puyuh kurang tersedianya bibit puyuh hasil persilangan dengan struktur breeding yang jelas sehingga dikhawatirkan terjadinya inbreeding. Dampak dari inbreeding akan menghasilkan turunan yang cacat, tingginya angka konversi ransum sehingga kurang efisiensi penggunaan ransum, penurunaan pertumbuhan dan umur dewasa kelamin yang lambat. Sehingga perlu dilakukan penelitian persilangan (Cross breeding) puyuh Hybrid dengan Coturnix coturnix japonica terhadap pertumbuhan turunannya. Tujuan dari penelitian ini yaitu untuk mengetahui pengaruh persilangan puyuh Hybrid terhadap pertumbuhan, konsumsi pakan, pertambahan bobot badan dan umur dewasa kelamin turunannya.

\section{MATERI DAN METODE}

\section{Waktu dan Tempat Penelitian}

\section{Tempat dan Waktu}

Penelitian ini dilaksanakan di Laboratorium Lapangan Peternakan (LLP) yang terletak di jalan Gampong Rukoh, Darussalam, Banda Aceh. Penelitian dilaksanakan selama 3 bulan dan dimulai dari bulan Juli hingga bulan September 2018.

\section{Materi Penelitian}

Penelitian ini menggunakan puyuh Coturnix coturnix japonica dan Hybrid dengan jumlah 80 ekor, yaitu 24 ekor untuk betina Coturnix coturnix japonica, 16 ekor jantan Coturnix coturnix japonica, 24 ekor betina Hybrid dan 16 ekor jantan Hybrid. DOQ diperoleh dari "Puyoeh Toeh Peucheh" yang beralamat di perumahan PU Irigasi, Ajuen, Peukan Bada, Aceh Besar dan dipelihara di Laboratorium Lapangan Peternakan selama 60 hari.

\section{Alat dan Bahan Penelitian}

\section{Alat Penelitian}

Alat-alat yang digunakan pada penelitian ini adalah kandang, tempat pakan, tempat minum, timbangan digital, mesin tetas, thermostat, termometer, tempat telur, laptop, alat tulis, alat sanitasi dan pembersih kandang lainnya.

\section{Bahan Penelitian}

Bahan-bahan yang digunakan pada penelitian ini yaitu pakan 511, 512, 324-1 M dan Eggstimulant.

\section{Metode Penelitian}

Penelitian dilakukan dengan pengumpulan data yaitu mengambil sampel dari populasi puyuh petelur hasil persilangan puyuh Coturnix coturnix japonica dan puyuh Hybrid selanjutnya dilakukan 
pengamatan sifat kuantitatif meliputi konsumsi pakan, pertambahan berat badan, konversi pakan dan melihat umur bertelur pertama hasil persilangan.

\section{Rancangan Penelitian}

Rancangan yang digunakan yaitu Rancangan Acak Lengkap (RAL) dengan 4 perlakuan, setiap perlakuan terdiri 4 ulangan dan setiap ulangan terdiri dari 5 ekor puyuh. Setiap perlakuan rasio puyuh jantan dan betina yaitu 2:3 ( 2 ekor puyuh jantan dan 3 ekor puyuh betina).

\section{Pelaksanaan Penelitian}

\section{Persiapan Kandang dan Peralatan}

Sebelum melakukan penelitian, persiapan kandang dan peralatan kandang dan juga tempat pakan dan tempat minum disterilkan dengan menggunakan desinfektan, lantai kandang dibersihkan dahulu menggunakan sapu kemudian dicuci menggunakan deterjen. Setelah kering, lantai kandang disiram dengan kapur cair dan disucihamakan menggunakan desinfektan. Kandang yang digunakan pada penelitian ini yaitu kandang baterai 4 tingkat dengan 16 blok yang masing-masing terdapat 5 ekor puyuh dengan kapasitas keseluruhan yaitu 80 ekor puyuh.

\section{Pemeliharaan}

Puyuh Coturnix coturnix japonica dan puyuh Hybrid dipelihara dari DOQ hingga berumur 60 hari. Setelah dewasa kelamin kemudian diseleksi berdasarkan berat badan kemudian dikawinkan dengan rasio 2:3 sesuai perlakuan yang terdiri dari 4 kali ulangan. Setelah 2 minggu puyuh bertelur, kemudian diambil dan dikoleksi selama 4 hari untuk dilakukan penetasan dalam mesin tetas selama 16-18 hari.

\section{Persiapan Mesin Tetas}

Mesin tetas yang digunakan, dibersihkan terlebih dahulu dengan menggunakan deterjen selanjutnya disemprot dengan desinfektan. Sebelum telur dimasukan ke dalam mesin tetas, mesin tetas dihidupkan selama 24 jam untuk mendapatkan temperatur yang stabil yaitu $38-38,5^{\circ} \mathrm{C}$ dan untuk mengatur kelembaban dilakukan dengan cara meletakan wadah berisi air dalam mesin tetas pada bagian bawah agar kelembaban mesin tetas mencapai $70 \%$. Kipas yang berada pada bagian atas dihidupkan agar temperatur dalam masin tetas merata.

\section{Penyiapan Telur Tetas}

Telur yang sudah dikoleksi dan diseleksi dibersihkan terlebih dahulu dengan menggunakan air hangat dan dilap dengan kain yang lembut kemudian dimasukan ke dalam mesin tetas.

\section{Peletakan Telur dalam Mesin Tetas}

Peletakan telur yang salah atau terbalik dapat menyebabkan embrio tidak normal. Peletakan telur tetas yang benar yaitu bagian ujung telur dibagian bawah dan bagian tumpul ke atas dengan kemiringan $45^{\circ}$. Pemutaran telur dilakukan 2 kali sehari yaitu pada pagi dan sore hari. Tujuan pemutaran yaitu untuk meratakan panas yang diterima oleh telur selama periode penetasan dan juga 
untuk mencegah agar embrio tidak menempel pada salah satu sisi kerabang telur sehingga menyebabkan embrio mati.

\section{Inkubasi Telur}

Telur diinkubasi selama 16-18 hari di dalam mesin tetas. Telur yang sudah menetas dipindahkan ke dalam brooder selama dua minggu lalu dipindahkan ke kandang baterai.

\section{Pengambilan Data}

Pengambilan data dalam penelitian ini yaitu konsumsi pakan, konversi pakan, pertambahan berat badan yang dilakukan selama 7 minggu mulai dari puyuh DOQ hingga dewasa kelamin dan umur bertelur pertama pada saat puyuh mulai bertelur.

\section{Parameter Penelitian}

Parameter yang diamati pada penelitian ini meliputi: Konsumsi pakan, pertambahan berat badan, konversi pakan (FCR), dan umur bertelur pertama.

\section{Analisis Data}

Data yang diperoleh diolah secara statistik dengan menggunakan analisa sidik ragam (Analisis of variance/ANOVA). Apabila terdapat perbedaaan antar perlakuan maka dilanjutkan dengan Uji Jarak Bergannda Duncan (Duncan Multiple Range Test/DMRT) (Steel dan Torrie,1991.

\section{PEMBAHASAN}

\section{Respon Perkawinan Silang Puyuh Hybrid Terhadap Konsumsi Pakan (gram/ekor/Minggu)}

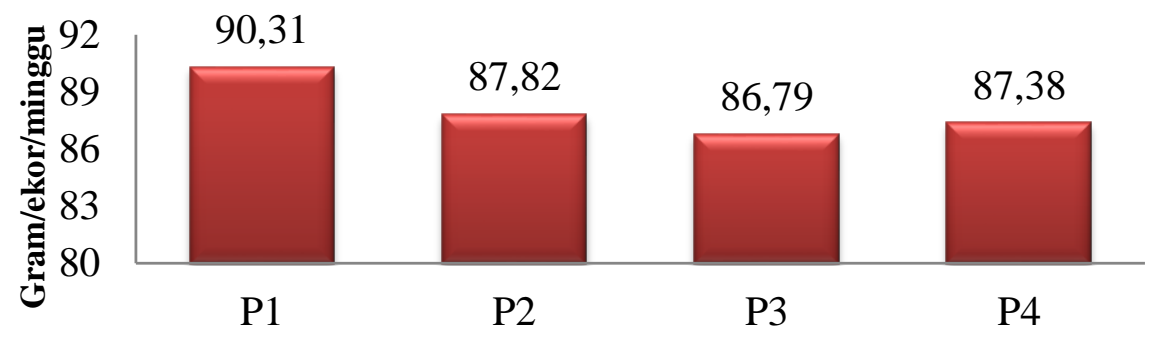

Gambar 1. Rataan Konsumsi Pakan Puyuh Hybrid Selama Penelitian (gram/ekor/Minggu)

Hasil analisis sidik ragam (Anova) menujukkan persilangan puyuh Hybrid dengan Coturnix coturnix japonica tidak berpengaruh nyata $(\mathrm{P}>0,05)$ terhadap konsumsi pakan pada setiap perlakuan. Rataan konsumsi ransum puyuh hybrid selama penelitian berkisar 86,79-90,31 gram/ekor selama 7 minggu. Rataan konsumsi ransum yang tertinggi pada P1 yaitu 90, 31 $\pm 0,77$ (gram/ekor) atau setara dengan 18,43 gram/ekor/hari. Rataan konsumsi ransum menunjukan bahwa setiap perlakuan P2, P3, $\mathrm{P} 4$ relatif sama dengan $\mathrm{P} 1$. Namun rataan konsumsi ransum cenderung lebih rendah pada P3 yaitu 
persilangan jantan Coturnix coturnix japonica dengan betina Hybrid. Hal ini dapat dikarenakan pengaruh genetik, konsumsi pakan puyuh Hybrid cenderung lebih sedikit bila dibandingkan puyuh Coturnix coturnix japonica.

Hasil penelitian ini lebih rendah bila dibandingkan hasil penelitian Achmanu et al. (2011) bahwa konsumsi ransum puyuh yaitu 21,05 gram/ekor/hari dan penelitian Yilzid et al. (2004) yaitu 29,63 gram/ekor. Namun demikian relatif sama dengan penelitian Lase et al. (2008) yang menyatakan bahwa puyuh betina silangan warna bulu coklat dan hitam memiliki rataan konsumsi ransum selama 7 minggu 88,52 gram/ekor. Selanjutnya penelitian Dewi et al. (2008) puyuh jantan hasil silangan warna bulu coklat dan hitam dengan rataan konsumsi ransum selama 7 minggu 78,25 gram/ekor.

\section{Respon Perkawinan Silang Puyuh Hybrid terhadap Pertambahan Bobot Badan (gram/ekor/minggu)}

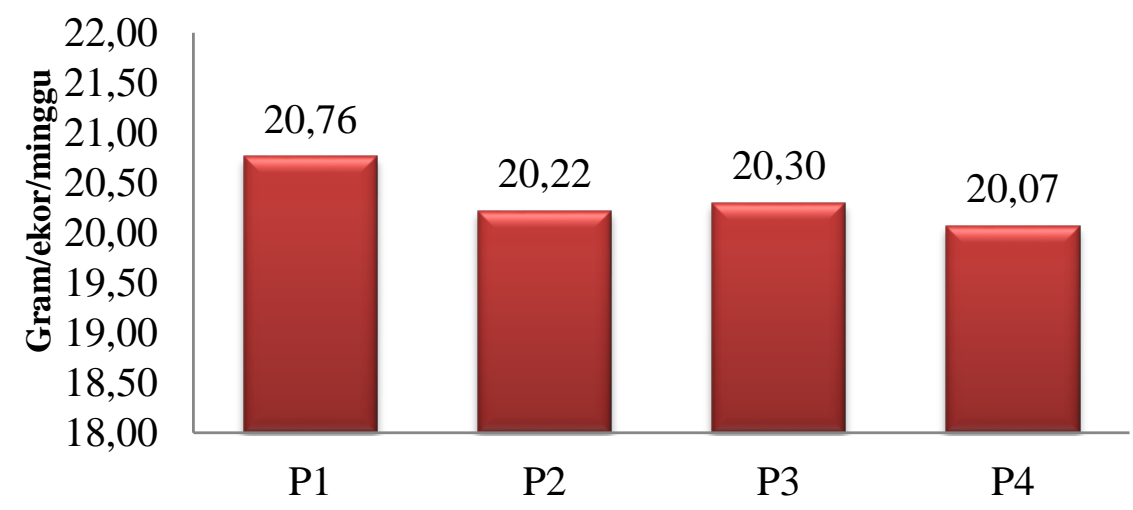

Gambar 2. Rataan Pertambahan Bobot Badan Puyuh Hybrid Selama Penelitian (gram/ekor/minggu)

Hasil analisis sidik ragam (Anova) pada perkawinan silang puyuh Hybrid dengan Coturnix coturnix japonica tidak berpengaruh nyata $(\mathrm{P}>0,05)$ terhadap pertambahan bobot badan. Dapat dilihat pada Gambar 4 rataan pertambahan bobot badan pada P3 dan P4 yaitu 20,30 dan 20,07 gram/ekor/minggu namun tidak jauh berbeda dari P1 dan P2. Penelitian ini lebih tinggi bila dibandingkan dengan penelitian Fauzi et al.(2016) rataan pertambahan berat badan pada puyuh (Coturnix coturnix japonica) betina umur 0-6 minggu galur warna coklat generasi 3 yaitu 19,11 gram/ekor/minggu. Penelitian Lase et al. (2008) menyatakan rataan pertambahan bobot badan puyuh betina silangan warna bulu coklat dan hitam selama 7 minggu adalah 18,829 gram/ekor/minggu. Penelitian Dewi et al. (2016) rataan pertambahan bobot badan puyuh jantan persilangan warna bulu hitam dan coklat selama penelitian yaitu 17, 29 gram/ekor/minggu. 


\section{Respon Perkawinan Silang Puyuh Hybrid terhadap Konversi Pakan}

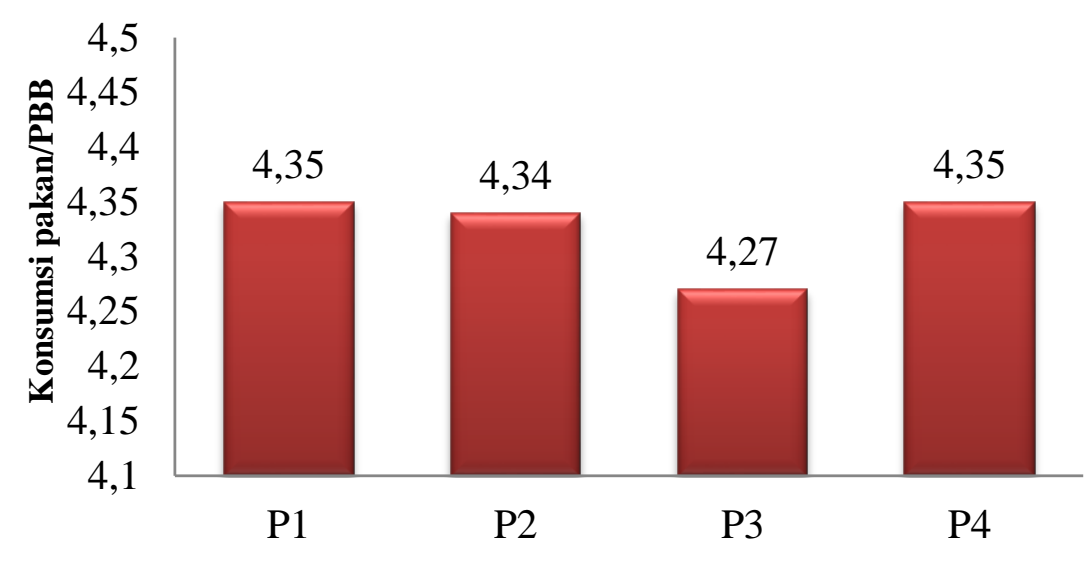

Gambar 3. Rataan Konversi Ransum Puyuh Hybrid Selama Penelitian

Berdasarkan hasil analisis sidik ragam persilangan puyuh Hybrid tidak berpengaruh nyata $(\mathrm{P}>0,05)$ terhadap konversi pakan. Hal ini disebabkan konsumsi pakan dan pertambahan bobot badan tidak berbeda nyata sehingga angka konversi pakan juga tidak berbeda nyata. Menurut Panjaitan et al. (2012) salah satu faktor yang mempengaruhi angka konversi pakan yaitu berat badan. Dari Gambarl 4 dapat dilihat pada P1, P2, P3 dan P4 rataan konversi pakan selama 7 minggu pada semua perlakuan relatif sama yaitu antara 4,7- 4,8. Puyuh hasil persilangan jantan Coturnix coturnix japonica dengan betina Hybrid memiliki angka konversi pakan yang baik yaitu 4,27 bila dibandingkan dengan puyuh yang bukan hasil persilangan. Tingginya angka konversi pakan disebabkan karena pada umur 6-7 minggu puyuh mengalami penurunan pertambahan berat badan dan baru mulai produksi sehingga puyuh membutuhkan energi yang cukup banyak untuk memproduksi telur walaupun masih rendah. Hal ini relatif sama dengan penelitian Lase et al. (2008) memiliki rataan konversi pakan puyuh petelur betina hasil silangan warna bulu coklat dan hitam selama 7 minggu ialah 4,55 . 


\section{Respon Perkawinan Silang Puyuh Hybrid terhadap Umur Bertelur Pertama}

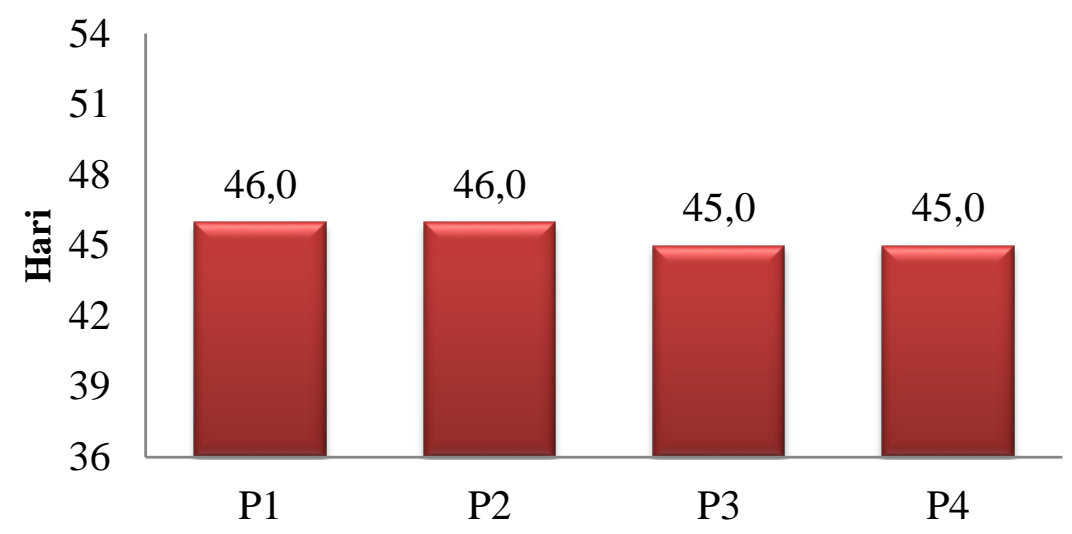

Gambar 4. Rataan Umur Bertelur Pertama pada Puyuh Hybrid Selama Penelitian (hari)

Hasil penelitian terhadap umur bertelur pertama persilangan puyuh Hybrid tidak berpengaruh nyata $(\mathrm{P}>0,05)$. Dapat dilihat pada Gambar 6 rataan umur bertelur pertama yaitu 45-46 hari. Puyuh hasil persilangan relatif lebih cepat bertelur dibandingkan puyuh yang bukan hasil persilangan. Hal ini sependapat dengan Masroh et al. (2014) bahwa umur bertelur pertama yang diberikan ransum komersil yaitu 47 hari. Namun menurut Nasution (2007) umur pertama kali bertelur puyuh yaitu 41 hari. Dan pendapat Nugroho dan Mayun (1990) puyuh pertama kali bertelur umur 42 hari atau setara 6 minggu.

Lambatnya umur bertelur pada penelitian ini dapat disebabkan karena pengaruh genetik dan umur induk sehingga mempengaruhi pertumbuhan dan umur dewasa kelamin turunannya. Menurut Wiradimaja et al. 2007 faktor yang mempengaruhi umur bertelur pertama yaitu pengaruh genetik, kesehatan, manajemen, ransum, pencahayaan dan bobot badan. Hal ini sependapat dengan Zainudin dan Syahruddin (2012) bahwa lambatnya puyuh bertelur berhubungan dengan genetik puyuh yang dipelihara.

\section{KESIMPULAN}

Berdasarkan hasil penelitian yang telah dilakukan dapat disimpulkan bahwa persilangan puyuh Hybrid dengan Coturnix coturnix japonica tidak berpengaruh terhadap konsumsi ransum, pertambahan bobot badan, konversi ransum dan umur bertelur pertama. Namun dari hasil persilangan jantan Coturnix coturnix japonica dengan betina Hybrid memperlihatkan bahwa angka konversi pakan cenderung lebih efisien dan umur bertelur pertama lebih cepat. 


\section{SARAN}

Adapun yang perlu disarankan berdasarkan penelitian ini:

1. Perlu adanya penelitian lebih lanjut untuk melihat turunanan puyuh Hybrid.

2. Disarankan sebaiknya tidak ada lagi perkawinan inbreeding dalam dunia Peterakan.

\section{DAFTAR PUSTAKA}

Achmanu, Muharlien dan Salaby. 2011. Pengaruh lantai kandang (rapat dan renggang) dan imbangan jantan-betina terhadap konsumsi pakan, bobot telur, konversi pakan dan tebal kerabang pada burung puyuh. Jurnal Ternak Tropika. 12: 1-14(2).

Achmanu dan Muharlien. 2011. Ilmu Ternak Unggas. Ub Press, Malang.

Dewi, R. R., E. Sujana dan A. Anang. 2016. Performa pertumbuhan puyuh (Coturnix coturnix japonica) petelur jantan hasil persilangan warna bulu hitam dan coklat umur 0-7 minggu di pusat pembibitan puyuh. Universitas Padjadjaran, Bandung.

Fauzi, M. F., A. Anang dan E. Sujana. 2016. Kurva pertumbuhan puyuh (Coturnix coturnix japonica) betina umur 0-6 minggu galur warna coklat generasi 3. Fakultas Peternakan Universitas Padjadjaran, Bandung.

Lase, H.G., E. Sujana dan H. Indrijani. 2008. Performa pertumbuhan puyuh (Coturnix coturnix japonica) petelur betina silangan warna bulu coklat dan hitam di pusat pembibitan puyuh. Unversitas Padjadjaran, Bandung.

Masroh, F. K., E. Sudjarwo, E. Widodo. 2014. Pengaruh penambahan tepung kulit singkong terfermentasi terhadap performans pertumbuhan dan umur pertama bertelur pada puyuh. Laporan Penelitian. Fakultas Peternakan Universitas Brawijaya, Malang.

Nasution. 2007. Pengaruh suplementasi mineral dalam ransum terhadap performa dan iofc burung puyuh umur 0-42 hari. Skripsi. Fakultas Petanian Unversitas Sumatra Utara, Medan.

Panjaitan, I., A. Sofian dan Y. Priabudiman. 2012. Suplementasi tepung jangkrik sebagai sumber protein terhadap kinerja

Wiradimadja, R., W. G. Piliang, M. T. Suhartono dan W. Manalu. 2007. Umur dewasa kelamin puyuh jepang betina yang diberi tepung daun katuk (Sauropus androgynus, I. Merr). Animal Production. 9(2): 67-72.

Zainuddin, S. dan Syahruddin. 2012. Pemanfaatan Tepung Keong Mas sebagai Subsitusi Tepung Ikan dalam Ransum Terhadap Performa dan Produksi Telur Puyuh. Laporan Penelitian. Fakultas Ilmu-Ilmu Petanian Universitas Negeri Gorontalo, Gorontalo. 